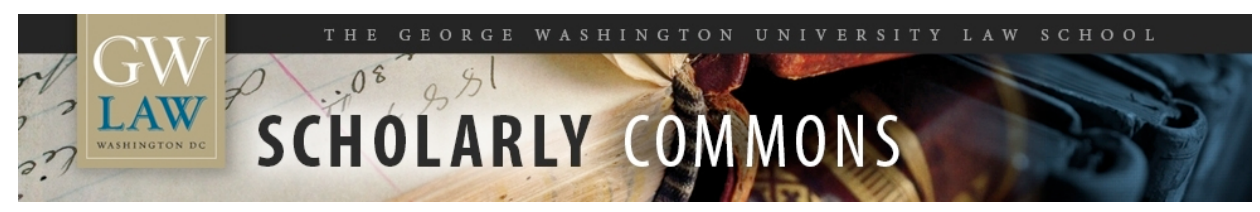

\title{
Antitrust Policy: A Century of Economic and Legal Thinking
}

William E. Kovacic

George Washington University Law School, wkovacic@law.gwu.edu

Carl Shapiro

Follow this and additional works at: https://scholarship.law.gwu.edu/faculty_publications

Part of the Law Commons

\section{Recommended Citation}

Kovacic, William E. and Shapiro, Carl, "Antitrust Policy: A Century of Economic and Legal Thinking" (1999). GW Law Faculty Publications \& Other Works. 633.

https://scholarship.law.gwu.edu/faculty_publications/633

This Article is brought to you for free and open access by the Faculty Scholarship at Scholarly Commons. It has been accepted for inclusion in GW Law Faculty Publications \& Other Works by an authorized administrator of Scholarly Commons. For more information, please contact spagel@law.gwu.edu. 


\section{Competition Policy Center \\ University of California, Berkeley}

Working Paper No. CPC99-09

Antitrust Policy: A Century of Economic and Legal Thinking

\section{William E. Kovacic}

George Washington University, Washington, D.C.

and Carl Shapiro

University of California at Berkeley,

October 1999

JEL Classification: K21, K00, N4

Keywords: antitrust, Sherman Act

William E. Kovacic is Professor of Law, George Washington University, Washington, D.C., wkovacic@main.nlc.gwu.edu.

Prepared for the Journal of Economic Perspectives.

Carl Shapiro is the Transamerica Professor Business Strategy, Haas School of Business, and Professor of Economics in the Economics Department, University of California at Berkeley, shapiro@haas.berkeley.edu.

This paper is available on-line at http://www.haas.berkeley.edu/groups/cpc/pubs/Publications.html 
ABSTRACT: CPC99-09

Passage of the Sherman Act in the United States in 1890 set the stage for a century of jurisprudence regarding monopoly, cartels, and oligopoly. Among American statutes that regulate commerce, the Sherman Act is unequaled in its generality. The Act outlawed "every contract, combination or conspiracy in restraint of trade" and "monopolization" and treated violations as crimes. By these open-ended commands, Congress gave federal judges extraordinary power to draw lines between acceptable cooperation and illegal collusion, between vigorous competition and unlawful monopolization.

By enlisting the courts to elaborate the Sherman Act' $s$ broad commands, Congress gave economists a singular opportunity to shape competition policy. Because the statute' $s$ vital terms directly implicated economic concepts, their interpretation inevitably would invite contributions from economists. What emerged is a convergence of economics and law without parallel in public oversight of business. As economic learning changed, the contours of antitrust doctrine and enforcement policy eventually would shift, as well.

This article follows the evolution of thinking about competition since 1890 as reflected by major antitrust decisions and research in industrial organization. We divide the U.S. antitrust experience into five periods and discuss each period' $s$ legal trends and economic thinking in three core areas of antitrust: cartels, cooperation, or other interactions among independent firms; abusive conduct by dominant firms; and mergers. 
Passage of the Sherman Act in the United States in 1890 set the stage for a century of jurisprudence regarding monopoly, cartels, and oligopoly. Among American statutes that regulate commerce, the Sherman Act is unequaled in its generality. The Act outlawed "every contract, combination or conspiracy in restraint of trade" and "monopolization" and treated violations as crimes. By these open-ended commands, Congress gave federal judges extraordinary power to draw lines between acceptable cooperation and illegal collusion, between vigorous competition and unlawful monopolization.

By enlisting the courts to elaborate the Sherman Act's broad commands, Congress gave economists a singular opportunity to shape competition policy. Because the statute's vital terms directly implicated economic concepts, their interpretation inevitably would invite contributions from economists. What emerged is a convergence of economics and law without parallel in public oversight of business. As economic learning changed, the contours of antitrust doctrine and enforcement policy eventually would shift, as well. ${ }^{1}$

This article follows the evolution of thinking about competition since 1890 as reflected by major antitrust decisions and research in industrial organization. We divide the U.S. antitrust experience into five periods and discuss each period's legal trends and economic thinking in three core areas of antitrust: cartels, cooperation, or other interactions among independent firms; abusive conduct by dominant firms; and mergers.

\section{The Early Days of the Sherman Act: 1890-1914}

Most economists in the late 19th century scorned the Sherman Act. ${ }^{2}$ At best, the statute seemed a harmless measure incapable of halting an irresistible trend toward firms of larger scale and scope. ${ }^{3}$ At worst, the law would impede attainment of superior efficiency promised by new forms of industrial organization. Few economists lauded the statute as a useful tool for controlling abusive business conduct. ${ }^{4}$ 
Beyond envisioning large gains from economies of scale and scope, economists at this time actively debated whether unbridled competition endangered industries with high fixed costs and low marginal costs, like railroads and utilities. Some argued that government ownership was needed to enable such industries to recover fixed costs. Others, anticipating Ramsey, Pigou, and Hotelling, recognized that price discrimination could enable firms to recover fixed costs. Schumpeter's classic History of Economic Analysis (1954) reflects the focus of the day. In discussing the 1870-1914 period, Schumpeter refers not to "industrial organization" but rather to "Railroads, Public Utilities, Trusts, and Cartels." ${ }^{5}$

Although the Sherman Act's first two decades featured no whirlwind of antitrust enforcement, the courts began shaping the law's vague terms. The Act's categorical ban upon "every" contract in restraint of trade required judges to develop principles for distinguishing between collaboration that suppressed rivalry and cooperation that promoted growth. Some early cases, such as United States v. Trans-Missouri Freight Association, ${ }^{6}$ applied such language literally, yet even these decisions recognized that prohibiting all agreements which curbed commercial freedom could imperil beneficial forms of cooperation, such as partnerships. In United States v. Addyston Pipe \& Steel Co., ${ }^{7}$ the court distinguished between "naked" trade restraints, where direct rivals simply agreed to restrict output and raise price, and reasonable "ancillary" restraints, which encumbered the participants only as much as needed to expand output or introduce a product that no single participant could offer. Judges also rejected arguments that price-fixing by competitors was benign because the cartelists set "reasonable" prices or desired only to halt an endless downward price spiral (Perelman 1994).

Early decisions also extended the suspicion of price restrictions to vertical relationships. In Dr. Miles Medical Co. v. John D. Park \& Sons. Co. (1911), the Supreme Court held that a minimum resale price maintenance (RPM) agreement, by which a manufacturer compels retailers to sell its products above a specified price, is illegal per se. The rule of Dr. Miles continues to govern such arrangements.

As the courts delineated rules for collusion and cooperation between firms, they struggled in these early years to come to grips with monopoly. The Sherman Act's language and legislative history 
indicated that Congress did not condemn the status of monopoly. Instead, the crucial initial analytical task for courts was to define the behavior which, when coupled with monopoly power, constituted illegal monopolization.

At first, the statute provided a feeble check upon the creation and exercise of market dominance. In 1895 in United States v. E.C. Knight Co. ${ }^{9}$ the Supreme Court tolerated a series of mergers that gave the Sugar Trust control over 98 percent of the country's sugar refining capacity. The Court found that the trust's manufacturing operations did not constitute interstate commerce within the Sherman Act's reach. The E.C. Knight outcome and executive branch indifference to the Sherman Act helped trigger a merger wave in which such firms as General Electric, International Harvester, du Pont, Eastman Kodak, U.S. Steel, and Standard Oil achieved preeminence (Stigler 1950: 27). Not until 1904, when it blocked the combination of the Northern Pacific and Great Northern railroads, ${ }^{10}$ did the Supreme Court show that the Sherman Act could forestall mergers to monopoly.

On the heels of its success in the Northern Pacific matter, the government filed several cases challenging the nation's industrial giants. In Standard Oil Co. v. United States (1911), ${ }^{11}$ the Supreme Court directly tackled the question of dominant firm conduct and left four enduring marks. First, the Court treated Standard's 90 percent share of refinery output as proof of monopoly. Future cases commonly would use high market shares as proxies for monopoly power Second, the Court established the "rule of reason" as the basic method of antitrust analysis. By this standard, judges would assess conduct on a case-by-case basis, although especially harmful behavior still might be condemned by bright line, per se rules. Third, the Court began classifying some behavior as unreasonably exclusionary. It ruled that Standard's selective, below-cost price cuts and buy-outs of rivals illegally created and maintained the firm's dominance. Finally, despite Standard's dire (and unfulfilled) predictions of industrial apocalypse, the Court broke the firm into 34 parts.

Though Standard Oil is the era's best known monopolization decision, the Supreme Court imposed another significant limit upon dominant firms in United States v. Terminal Railroad Association of St. Louis (1912). ${ }^{12}$ There the Court forbade various railroads to use their control of terminal facilities 
at the main crossing of the Mississippi River in St. Louis to discriminate against rivals. In a ruling with continuing significance for network industries, the Court forced the defendants to give outsiders access on reasonable terms, observing that the Interstate Commerce Commission could solve the problem of setting fair access prices. ${ }^{13}$

Standard Oil ultimately became known as one of the government's finest hours, but Congress did not view it that way in 1911. Congress feared that the Supreme Court's apparent softening of the law, by reading the Sherman Act's ban on "every" trade restraint to bar only "unreasonable" restraints, foreshadowed continuing efforts by conservative judges to narrow the statute unduly. This concern inspired enactment in 1914 of the Clayton Act and the Federal Trade Commission Act. The Clayton Act reduced judicial discretion by specifically prohibiting certain tying arrangements, exclusive dealing agreements, interlocking directorates, and mergers achieved by purchasing stock. The FTC Act ended the executive branch's public enforcement monopoly by forming an administrative body to make antitrust policy.

\section{Ascent of the Rule of Reason: 1915-1936}

Following the Standard Oil and Terminal Railroad decisions, the passage of the Clayton Act, and the creation of the FTC, it might seem that antitrust enforcement was about to step into high gear. Instead the antitrust system entered a period of relative repose. ${ }^{14}$ From 1915 until the mid-1930s, the courts relied heavily on reasonableness tests to evaluate business conduct and often treated suspect behavior permissively. In the same era, the executive branch discouraged aggressive prosecution by the Justice Department and the FTC.

The shift in emphasis had several sources. The first was ascent of the "associationalist" vision of business-government relations. Experience with the War Industries Board in World War I led many economists, business leaders, and government officials to believe that the business-government collaboration that guided the wartime mobilization provided the best way to organize the economy in times of peace. The associationalists received strong support from Herbert Hoover who, as 
Secretary of Commerce and as President, urged businesses to cooperate through trade associations to exchange information and curb the wasteful features of competition. ${ }^{15}$

To many observers, the economic collapse in 1929 repudiated the competitive model of economic organization and verified the associationalist preference that the government take stronger steps to orchestrate commerce. Advocates of close coordination between government and industry exercised considerable influence in designing the National Industrial Recovery Act (NIRA) and other planning experiments of the early New Deal. ${ }^{16}$ By mid-decade, Congress imposed comprehensive controls on entry and pricing in sectors such as transportation and passed the Robinson-Patman Act (1936), which sought to prevent national retailing chains from expanding at the expense of small stores. As support for competition waned, antitrust policy receded as well.

Supreme Court decisions in this era affecting collusion and cooperation between firms reflected tolerant treatment. With regard to relations among competitors, the Court in Board of Trade of the City of Chicago v. United States $(1918)^{17}$ upheld limits that a commodities exchange placed on prices for after-hours trading. The Court said the restraints should be evaluated through a comprehensive inquiry into their history, purpose, and effect. This multi-factored rule of reason might make analysis more accurate, but such an approach could require costly, time-consuming efforts to gather and evaluate information -- conditions that tended to favor defendants. For practices affecting distribution to downstream firms, the Supreme Court in United States v. Colgate \& Co. (1919) ${ }^{18}$ permitted producers to announce a favored distribution policy and "unilaterally" refuse to deal with downstream firms that did not comply, thus narrowing the Dr. Miles per se ban upon minimum RPM.

In Maple Flooring Manufacturers' Association v. United States (1925) the Court also took a benign view of arrangements for sharing price and output data among rivals. ${ }^{19}$ Maple Flooring holds special interest for economists today because it featured the Supreme Court's first citation to an economist's work in an antitrust decision -- in this instance, to underscore how access to information might enable producers to make efficient output and pricing decisions. Maple Flooring's author was Harlan Fiske Stone, a former dean of Columbia Law School, who favored using social science literature to resolve 
legal issues.

Despite a largely tolerant attitude toward cooperation between firms, Stone and his Supreme Court colleagues in the 1920s still indicated that some forms of collaboration deserved summary condemnation. In United States v. Trenton Potteries Co. (1927), ${ }^{20}$ the Court suggested that unadorned agreements by competitors to set prices were generally so pernicious that courts might flatly prohibit them, even though using an elaborate rule of reason might validate such arrangements in rare cases. Trenton Potteries appeared to reject Chicago Board of Trade's notion that all agreements among competitors deserved expansive, fact-intensive review.

By the early 1930s, in the depths of the Depression, even the Court's stand against naked horizontal output restrictions wavered. In Appalachian Coals, Inc. v. United States (1933), ${ }^{21}$ the Court refused to condemn an output restriction scheme embodied in a joint marketing agreement proposed by coal producers in the eastern U.S. Like the Congress at the time, the Court appeared to have lost faith in free market competition and welcomed experiments with sector-wide private ordering. Appalachian Coals later came to be seen as a Depression-era aberration.

Along with loose rules on cooperation between rivals, the 1915-1936 era marks the longest lapse for antitrust controls on dominant firm behavior. Although the courts ordered noteworthy divestitures in some monopolization cases in the late 1910s, decisions exculpating large defendants were the norm. In United States v. United States Steel Corp. (1920), ${ }^{22}$ the Supreme Court slighted evidence of outright collusion and exonerated the nation's leading steel producer on monopolization charges. The Court credited testimony by U.S. Steel's rivals, who praised the defendant's willingness to let them prosper beneath its generous price umbrella. The company's declining market share -- from over 80 percent in 1910 to about 40 percent in 1920 -- also convinced that Court that it lacked market power. ${ }^{23}$ U.S. Steel also exposed the Sherman Act's frailty as a merger control device by revealing that firms could consolidate a great deal before courts would find illegal monopolization.

When the Supreme Court confronted cases involving market power measurement, it tended to accept Kovacic and Shapiro, Antitrust Policy: A Century of Economic and Legal Thinking, Page 7 
broad market definitions that made a finding of dominance less likely. In Standard Oil Co. v. United States (1931), ${ }^{24}$ the Court upheld a patent pool by which several major refiners set the royalties to be paid for exploiting catalytic cracking technology. Key to the decision was the definition of the relevant market. If cracking technology were the relevant product, the refiner' market share would exceed 60 percent. Alternatively, if the relevant product encompassed all refining capacity, including older distillation technology, the defendants' share would be only 26 percent. The Court embraced the second alternative and concluded that the refiners probably lacked power to raise prices.

The FTC found itself by turns unwilling and unable to contribute much to antitrust enforcement. True, Section 5 of the FTC Act broadly prohibited unfair methods of competition. But the early FTC suffered from dismal appointments and bumptious leadership -- Louis Brandeis, the FTC Act's chief author, called the agency's early commissioners 'a stupid administration. ${ }^{, 25}$ In one decision after another, the courts in the 1920s narrowly interpreted the agency's expansive substantive mandate and information gathering powers. Especially damaging was Federal Trade Commission v. Eastman Kodak Co. (1927), ${ }^{26}$ where the Supreme Court said the FTC lacked power under Section 5 to order divestiture to undo anti-competitive asset acquisitions. Had the FTC prevailed, it might have become the government's premiere merger enforcement agency. Not until the late 1960s did the FTC gain judicial rulings that repaired the damage from the 1920 s. $^{27}$

It is difficult during this period to detect significant direct effects of economic thinking and research on judicial antitrust decisions. The courts emphasized market share as an indicator of market power, while economists focused more upon the beauty of scale economies and their implications for prices and market structure. While Pigou's writings on price discrimination have proven durable, they provided no basis for the prohibitions on price discrimination in the Robinson-Patman Act. Nor does the notion of efficient price discrimination by a monopolist to recover fixed costs (that is, Ramsey pricing) appear in the cases of this era. Economists of this time were also grappling with the general problem of how to develop a theory of increasing returns together with monopolistic competition (Chamberlin, 1933 [containing work dating as early as 1921]; Robinson, 1933). Only much later, in cases involving mergers of firms with branded products, does this thinking about product 
differentiation enter the legal mainstream.

\section{Emphasis on Market Structure and Per Se Rules: 1936-1972}

By the mid-1930s, the economic planning models that inspired great hope early in the New Deal had lost their luster. Franklin Roosevelt turned his ear toward advisors who believed the key to economic restoration was competition. ${ }^{28}$ From 1936 through 1940, Roosevelt's top appointees to the Justice Department, culminating with Thurman Arnold's selection to head the Antitrust Division, mounted ambitious attacks on horizontal collusion and single-firm dominance.

The trustbusting revival drew intellectual strength from the work of University of Chicago economists Henry Simons, Jacob Viner, and Frank Knight. ${ }^{29}$ Simons in particular assailed the statist assumptions of New Deal planning experiments such as the NIRA and advocated robust antitrust enforcement, including steps to deconcentrate American industry. ${ }^{30}$ Here we see champions of free markets promoting antitrust and competition as preferable to government regulation, planning, or ownership. ${ }^{31}$

The invigoration of antitrust enforcement in the late 1930s reflected both a heightened suspicion of corporate gigantism and a search for ways to simplify the government's burden of proof. Because the rule of reason formulated in cases such as Chicago Board of Trade often entailed an indeterminate inquiry that exonerated defendants, many commentators urged courts to simplify the plaintiff's burden of proof.

Several Supreme Court decisions accomplished these shifts in policy and abandoned the philosophy of Appalachian Coals (1933). In United States v. Socony-Vacuum Oil Co. (1940), ${ }^{32}$ the Court condemned collective efforts by refiners to buy "distress" gasoline produced by independents. The Court emphasized that horizontal price fixing agreements would be condemned summarily and treated as crimes, regardless of their actual effects. The Court warned that business managers who tried privately to recreate the planning schemes that government officials previously had approved acted at their peril. In hindsight, Socony's ban upon all arrangements that affect price seems extreme, but 
its aim in 1940 was to reaffirm the primacy of competition and revitalize the Sherman Act. In Socony and in Interstate Circuit, Inc. v. United States (1939), which found an illegal horizontal conspiracy based on circumstantial evidence, the Supreme Court showed that unlawful agreements could be proven without direct evidence such as a participant's testimony and that such arrangements, if detected, could be punished severely.

The revival of enforcement against price fixing and market allocation cartels refocused attention on antitrust's definition of "agreement." After toying with the possibility of treating oligopolistic interdependence as a form of agreement, the Supreme Court in Theatre Enterprises, Inc. $v$. Paramount Film Distributing Corp. (1954) ${ }^{33}$ ruled that proof of "conscious parallelism," without more, could not sustain a finding that the defendants acted jointly, and thus could not establish an antitrust violation. In the years to follow, litigants and courts would spend vast resources to identify the "plus factors" which, when added to proof of conscious parallelism, would permit a jury to infer an illegal agreement.

The use of per se tests to condemn conduct extended well beyond the price-setting behavior at issue in Socony and Interstate Circuit. In this era, the Supreme Court used per se rules to ban tying arrangements that conditioned the sale of one product upon the buyer's agreement to purchase a second product; ${ }^{34}$ non-price vertical restraints by which a manufacturer limited its retailers to specific geographic areas ${ }^{35}$ group boycotts by which a full-service retailer threatened not to deal with manufacturers who sold to discounters; ${ }^{36}$ and horizontal agreements to allocate markets or customers. ${ }^{37}$ The Court also characterized the adoption of exclusive sales territories by participants in a marketing joint venture as per se unlawful. ${ }^{38}$

As the courts tightened rules for collusion and cooperation between firms, they also grew more willing to find that dominant firms had acted improperly. In United States v. Aluminum Co. of America (1945), ${ }^{39}$ the court treated the fulfillment of new demand through the preemptive addition of capacity as wrongful. In United States $v$. United Shoe Machinery (1954), ${ }^{40}$ the court praised the defendant's R\&D record and noted how its customers approved its policy of only leasing (and not 
selling) its machines, yet still condemned this practice. In Utah Pie Co. v. Continental Baking Co. (1967), ${ }^{41}$ the Supreme Court condemned a national bakery's use of localized price cuts to challenge the leading local producer. Courts routinely slighted efficiency rationales for challenged behavior, revealing an implicit suspicion that superior performance never could explain dominance. Few decisions of this era command praise today. ${ }^{42}$

In the Celler-Kefauver Act of 1950, Congress bolstered merger control by banning asset or stock consolidations which fell short of creating dominance. This measure enabled the government to press aggressive attacks against categories of horizontal and vertical transactions that previously had withstood judicial scrutiny. In Brown Shoe Co.v. United States (1962), ${ }^{43}$ perhaps the most famous case under the 1950 Act, the Supreme Court invalidated a merger that would have yielded a horizontal market share of 5 percent and generated a vertical foreclosure of under 2 percent. Brown Shoe ruled that the parties' market share, though low overall, could be deemed excessive in certain "submarkets." The Court also held that non-efficiency goals, such as preserving small firms, were relevant to applying the statute.

In 1963 in United States v. Philadelphia National Bank, ${ }^{44}$ the Court allowed the government to establish a prima facie case of illegality by proving an untoward increase in concentration. The Court cautioned that market share data alone was not decisive and the government's prima facie case was rebuttable. In practice, however, market shares routinely determined outcomes. Later cases such as United States v. Von's Grocery Co. $(1966)^{45}$ and United States v. Pabst Brewing Co. $(1966)^{46}$ placed horizontal mergers creating market shares as low as 4.5 percent at risk. Rebuttal efforts usually failed. Among other arguments, the Supreme Court held efficiency claims to be, at best, irrelevant and possibly a factor weighing against approval of the merger. ${ }^{47}$ By the mid-1960s, business managers realized that antitrust's pendulum had swung dramatically away from the permissiveness of the 1920s and early 1930s. In a famous dissent in Von's Grocery, Justice Potter Stewart captured the spirit of the time by lamenting that the sole consistency he could perceive in Supreme Court merger decisions was that "the Government always wins." ${ }^{48}$ Most commentators today share Stewart's gloomy assessment of merger jurisprudence in the 1960s and view the Supreme Court's 
antipathy toward mergers and doubts about market forces as indefensible.

There is considerable consistency between judicial decisions and economic thinking during the 1940s, 1950s, and 1960s. Although it is uncertain how and to what extent each perspective influenced the other, judicial application of economic concepts lagged behind new scholarly developments (Kovacic 1992). Even as courts strove to deal with the many tight-knit industrial oligopolies of the day, economists came to realize that departures from the perfect competition model are normal, indeed inevitable, even in "competitive" industries. This view led economists to articulate vague criteria for whether a market was "workably" competitive (Clark, 1940; Markham, 1950). As judges grappled with how to treat parallel conduct in tight oligopolies without explicit evidence of collusion, economists were exploring the pricing behavior of oligopolists, including "price leadership," where a single large firm initiates price changes and others typically follow (Stigler, 1947; Fellner, 1949; Markham, 1951). This work showed how price leadership could explain pricing patterns observed in tight-knit oligopolies, but it gave judges no simple formula for setting clear rules to distinguish illegal agreements from mere conscious parallelism that could yield similar outcomes. ${ }^{49}$

As courts in this era were emphasizing measures of market structure and concentration, industrial organization thinking focused on articulating and developing the "structure, conduct, performance" paradigm often associated with the work of Joe Bain (1956; see also Mason, 1939). This framework encouraged empirical researchers to seek relationships between market concentration and performance measures such as price/cost margins. ${ }^{50}$ Despite an emphasis on market concentration in making this assessment, economists of this time recognized that an industry's long run performance is likely to hinge more on its level of innovation than on the four-firm concentration ratio or departures of prices from marginal cost. Finally, both the courts and economists of this time tended to downplay efficiencies associated with large-scale enterprises.

\section{The Ascent of the Chicago School: 1973-1991}

By the early 1970s, the extreme activism in antitrust law, reflected in public enforcement policy and 
Supreme Court decisions, had attracted harsh criticism from commentators known as the Chicago School, including legal scholars such as Robert Bork and Richard Posner. This was not the first time that the University of Chicago had influenced competition policy. In the 1930s, Chicago-based theorists such as Henry Simons played a key role in attacking central planning and promoting deconcentration policies. The new Chicago School originated in the work of Aaron Director in the late 1940s and early 1950s. ${ }^{51}$ Like Simons, the new Chicago School abhorred comprehensive regulation of entry and prices. Unlike their predecessors, the new Chicago scholars emphasized efficiency explanations for many phenomena, including industrial concentration, mergers, and contractual restraints, that antitrust law acutely disfavored in the 1950s and 1960s.

Economically astute attorneys such as Bork, Posner, Frank Easterbrook, and Ernest Gellhorn and legally sophisticated economists such as Betty Bock took new Chicago School analytical precepts and translated them into operational principles that judges readily could apply. ${ }^{52}$ These commentators questioned many rules of per se illegality that the Supreme Court created from 1940 to 1972 and argued that some conduct, such as vertical restraints, was so often benign or pro-competitive that courts should uphold it with rules of per se legality.

By the mid-1970s, the perspectives of these and like-minded commentators increasingly gained judicial approval. At least two key factors accounted for this receptivity. The first was a change in judicial appointments. Many of Richard Nixon's appointees to the Supreme Court (most notably on antitrust issues, Lewis Powell) and the lower courts had comparatively narrow preferences for antitrust intervention. The second factor was a sense that U.S. firms were losing ground in international markets and surrendering market share at home. This perception increased sensitivity to efficiency arguments.

Litigation over vertical restraints provided the occasion for Chicago School efficiency perspectives to enter antitrust's doctrinal mainstream. The pivotal event was the Supreme Court's decision in Continental T.V. Inc. v. GTE Sylvania Inc. (1977), ${ }^{53}$ which held that all non-price vertical restrictions -- like the location clauses challenged in this case -- warrant rule of reason analysis. The Court 
prominently cited Chicago School commentary and emphasized that the analysis of economic effects provided the proper basis for evaluating conduct under the antitrust laws. Minimum retail price maintenance agreements remained illegal per se, but later decisions toughened evidentiary tests for proving the existence of such arrangements. ${ }^{54}$

Supreme Court decisions of this period concerning rules for collusion and cooperation by firms reflect tension between cases favoring the absolutist approach of Socony (1940) -- such as Arizona v. Maricopa County Medical Society $(1982)^{55}$ and Federal Trade Commission v. Superior Court Trial Lawyers Association (1990) ${ }^{56}$-- and those endorsing a fuller rule of reason analysis, such as Broadcast Music, Inc. v. Columbia Broadcasting System, Inc. (1979) ${ }^{57}$ and NCAA v. Board of Regents (1984).$^{58}$ Although the Court has not reconciled this tension, most of its decisions in this period perceived the need for an analytical middle ground between per se condemnation and elaborate rule of reason analysis..$^{59}$

During this period, the Justice Department and the FTC brought numerous cases challenging dominant firm conduct. With rare, noteworthy exceptions such as United States v. AT\&T Co. (1982), ${ }^{60}$ which broke up the Bell system, these cases usually failed (Kovacic, 1989: 1106-09). For the most part, the courts gave dominant firms considerable freedom to choose pricing, ${ }^{61}$ product development, ${ }^{62}$ and promotional strategies. ${ }^{63}$

A more permissive climate developed for mergers, as well. In United States v. General Dynamics Corp. (1974), ${ }^{64}$ the government suffered its first Supreme Court defeat under the Celler-Kefauver Act. General Dynamics showed that the rebuttal possibilities recognized in Philadelphia National Bank (1963) were not illusory. Several influential lower court cases used ease of entry to permit mergers that yielded high market shares. ${ }^{65}$ Other decisions recognized at least the conceptual validity of efficiency justifications. ${ }^{66}$ Perhaps most important, the court of appeals in United States v. Baker Hughes, Inc. (1990), ${ }^{67}$ with a panel including future Supreme Court justices Clarence Thomas and Ruth Ginsburg, ruled that the defendant's burden of proof in a merger case depends on whether the plaintiff relies solely on market share data or provides further evidence of likely anti-competitive 
effects. These decisions parallel similar developments in the federal merger guidelines, which disavowed the most extreme enforcement possibilities created by Supreme Court merger decisions in the 1960s. ${ }^{68}$

During this era, it is clear that the courts, under the Chicago School's influence, were trimming back antitrust doctrine. Yet the same analytical tools that economists used to challenge interventionist antitrust doctrines of the 1950s and 1960s, by showing that certain practices often could increase efficiency and boost competitiveness, were simultaneously offering new methods for arguing that many business practices sometimes could harm competition.

One prominent example of this dynamic occurred in the area of "predatory pricing," in which a firm temporarily sells below cost to subdue rivals and then collects monopoly rents. While economists for decades had criticized many predatory pricing cases, government enforcers remained keen on these matters through the 1970s. But the courts in the 1970s paid careful attention to the economic literature, to the extent that the term "average variable cost" now commonly appears in predatory pricing decisions (American Bar Association, 1997: 253-66). By the mid-1980s, in Matsushita Electric Industrial Co.v. Zenith Radio Corp. (1986), ${ }^{69}$ the Supreme Court was saying that predatory pricing rarely made business sense, because the predator had little probability of sustaining a future monopoly long enough to recoup losses incurred through below-cost sales. Yet at the same time, game theorists were showing how predation could rationally occur in a world with imperfect information and signaling, if potential entrants had long memories and declined to challenge a deeppocket incumbent who had displayed a willingness to respond to entry by selling below cost.

Game-theoretic methods dominated industrial organization theory in the 1970s and 1980s. The flexibility of game theory allowed economic theorists to generate equilibrium predictions in settings involving a wide range of conduct, from R\&D decisions to advertising to product positioning, as well as the classic problem of oligopolistic pricing. However, the same flexibility made general predictions hard to come by. ${ }^{70}$ Some conduct, such as long-term contracts with key customers or preemptive capacity expansion, could deter entry and entrench dominance, but they also could generate 
efficiencies. The only way to tell in a given case appeared to be for the antitrust agencies and the courts to conduct a full-scale rule-of-reason inquiry.

\section{Towards a Post-Chicago Synthesis: Since 1992}

Antitrust decisions and government enforcement policy since the mid-1990s have begun to reflect the flexibility of recent analytical perspectives. ${ }^{71}$ The most noteworthy feature of recent cases concerning collusion or cooperation between firms is the search for manageable analytical techniques that avoid the complexity of the traditional rule of reason yet supply a richer factual analysis than per se tests. In California Dental Association v. Federal Trade Commission (1999), ${ }^{72}$ the Supreme Court acknowledges the conceptual validity of analytical models lying between the per se and full-fledged rule of reason poles, but does not specify how to structure such inquiries. Further development of such methodologies may occur in the Justice Department's recent challenge to the membership rules of Visa and MasterCard, which prevent member financial institutions from issuing credit cards that compete against Visa and MasterCard, ${ }^{73}$ and in proposed federal guidelines on collaboration among competitors. $^{74}$

Government efforts to combat collusion in the 1990s have applied game theory in two notable ways. First, the Justice Department adopted a policy that gives criminal immunity to the first cartel member to reveal the cartel's existence. ${ }^{75}$ Recent criminal enforcement results indicate that the strategy elicits valuable information. In 1999, using data supplied by a cartel member under the new policy, the Justice Department obtained guilty pleas from BASF and Roche to pay a total of $\$ 750$ million in criminal fines (an amount surpassing the sum of all Sherman Act criminal fines since 1890) for fixing vitamin prices. $^{76}$ Second, the government has prosecuted behavior that facilitates coordination, not just the coordination itself. For example, in the early 1990s, the government obtained a settlement from several airlines to bar the use of computer reservation systems to coordinate prices. ${ }^{77}$ As the Internet emerges as a key conduit for commerce, we will see more enforcement actions and judicial decisions on how firms may interact in cyberspace (Baker 1996). 
Perhaps the most important modern judicial use of game theory, the economics of information, and transaction-cost economics is Eastman Kodak Co. v. Image Technical Services, Inc. ${ }^{78}$ Kodak was accused of monopolizing a market consisting of parts and service for its own photocopiers. A lower court granted summary judgment for Kodak, which argued that its 20 percent share of sales of new copiers made it irrational to impose unreasonable aftermarket restraints on its installed base. The court of appeals overturned the grant of summary judgment, and the Supreme Court affirmed. The Court extensively cited game-theoretic commentary, much as it had quoted Chicago School scholars in Sylvania (1977). Relying heavily on notions such as imperfect information and lock-in as sources of market power, the Court said a trial was necessary to assess Kodak's ability to exploit its installed base and evaluate its business justifications. ${ }^{79}$

At first it seemed that Kodak might transform jurisprudence governing dominant firm conduct, and this may still prove possible. Since 1992, however, lower court decisions have tended to limit Kodak's application to a relatively demanding set of conditions. Moreover, the possibility that Kodak heralded a major expansion of antitrust liability weakened after Brooke Group Ltd. v. Brown \& Williamson Tobacco Corp. (1993). ${ }^{80}$ There the Supreme Court established the formidable requirement that predatory pricing plaintiffs prove that the defendant is likely to recoup its investment in below-cost sales once the plaintiff has exited. In a recent lawsuit that alleges predatory pricing by American Airlines, the Justice Department is using game theory concepts to show that recoupment is likely. ${ }^{81}$

In general, merger analysis has become more heavily economic. Economic concepts pervade the federal merger guidelines, and merger analysis, whether performed by prospective merger partners or antitrust agencies, routinely involves close collaboration between economists and attorneys. Although the Supreme Court has said nothing about substantive merger rules since $1975{ }^{82}$ lower court decisions and government enforcement guidelines continue to deviate from standards the Court endorsed in the 1960s. These developments have both toughened and loosened antitrust enforcement. Some cases, such as the rejection of the Staples/Home Depot merger (1997), ${ }^{83}$ have analyzed competitive effects in seemingly narrow submarkets and have used electronic data from cash registers to measure market power directly by analyzing how the business at one chain affected the 
other. However, in 1997, the federal agencies amended their merger guidelines to account more generously for merger synergies in analyzing competitive effects. This approach could make the law more friendly to mergers in some cases.

In recent years, antitrust enforcement has increasingly focused on innovation issues, as suggested by the release in 1995 of federal guidelines for licensing intellectual property. ${ }^{84}$ The recent concern with innovation may seem a slow reaction to Schumpeter's (1942) observation decades ago that innovation is the prime determinant of economic performance and growth. But modern policy reflects more recent work by economists showing how technology spurs growth, the role of patents in promoting or perhaps retarding innovation, and the impact of licensing. The FTC's recent suit against Intel for withdrawing cooperation from its microchip customers ${ }^{85}$ involved a highly innovative industry that relies heavily on cross licensing. In the Justice Department's battle against Microsoft, ${ }^{86}$ both parties depict themselves as champions of innovation. The government's theory in Microsoft draws extensively from game theory involving strategic entry deterrence and raising rivals costs.

For the future, two related challenges confront the 1990s approach to antitrust enforcement, capable as it is of generating various results. One is for economists and attorneys to devise analytical techniques that accurately identify complex business practices as being pro-competitive or anticompetitive. The second is to adapt such techniques to formulate rules that are suited to the capabilities of enforcement agencies and courts and give the business community stable, predictable bases for designing business plans. Recent prosecutions such as the abuse of dominance cases against American Airlines and Microsoft place a premium on the ability of the antitrust system to do both of these things.

\section{Conclusions}

The Sherman Act and its offshoots, as applied through the twists and turns of doctrine and enforcement in the 20th century, have attained almost constitutional stature in America. ${ }^{87}$ No other country has adopted an antitrust statute that contains equally broad substantive provisions and relies 
so heavily on a common law method of judicial interpretation to implement them. The consciously evolutionary quality of the U.S. antitrust statutes, with their implicit recognition of the need to adjust doctrine over time in light of experience and new learning, gives economists considerable power to influence competition law and policy.

Economists have made two major contributions to the U.S. antitrust regime. The first is to make the case for competition as the superior mechanism for governing the economy. Throughout the 20th century, America's antitrust laws have coexisted uneasily with policies that favor extensive government intervention in the economy through planning, ownership, or sweeping controls over prices and entry. Economists have informed the debate about the relative merits of competition by illuminating the costs of measures that suppress rivalry with the ostensible aim of serving the public interest.

The second significant contribution of economists has been to guide the formation of antitrust policy. Economic learning has exerted an increasing impact on antitrust enforcement. In the first half of the 20th century, one finds little direct impact of economic research on the major court cases. The influence increases in the century's second half, but usually with a lag. Today, the links between economics and law have been institutionalized with increasing presence of an economic perspective in law schools, extensive and explicit judicial reliance on economic theory, and with the substantial presence of economists in the government antitrust agencies. The availability of new data sources like electronic point-of-purchase data, the refinement of flexible game-theoretic models, and the new emphasis on innovation assures that robust arguments over the proper content of competition policy will flourish into the 21 st century. 


\section{References}

American Bar Association, Section of Antitrust Law. Antitrust Law Developments, $4^{\text {th }}$ Edition, Chicago, American Bar Association, 1997.

Bain, Joe S. Barriers to New Competition, Cambridge, Harvard University Press, 1956.

Baker, Jonathan B. Identifying Horizontal Price Fixing in the Electronic Marketplace, Antitrust Law Journal, 65, Fall 1996, pp. 41-__.

Baker, Jonathan B. Developments in Antitrust Economics. Journal of Economic Perspectives, 13, Winter 1999, pp. 181-94.

Chamberlin, Edward H. The Theory of Monopolistic Competition. Cambridge, Harvard University Press, 1933.

Clark, J.M. "Toward a Concept of Workable Competition," American Economic Review 30, 241-256, June 1940.

Ely, Richard T. Monopolies and Trusts. 1900.

Fellner, William. Competition Among the Few, New York Alfred A. Knopf, 1949.

Fisher, Franklin M. "Games Economists Play: A Non-Cooperative View," Rand Journal of Economics, Spring 1989, pp. 112-24.

Gaskins, Darius, "Dynamic Limit Pricing: Optimal Pricing Under the Threat of Entry," Journal of Economic Theory, 3, September 1971, 306-322.

Gavil, Andrew I. After Daubert: Discerning the Increasingly Fine Line Between the Admissibility and Sufficiency of Expert Testimony in Antitrust Litigation. Antitrust Law Journal, 65, Fall 1997, pp. 663-

Hawley, Ellis W. Herbert Hoover, the Commerce Secretariat, and the Vision of an 'Associative State,' 1921-1928. Journal of American History, 61, June 1974, pp. 116-40.

Hawley, Ellis W. The New Deal and the Problem of Monopoly. Princeton, Princeton University Press, 1966.

Hofstadter, Richard. The Paranoid Style in American Politics and Other Essays. New York, Alfred A. Knopf, 1966. 
Kovacic, William E. The Antitrust Paradox Revisited: Robert Bork and the Transformation of Modern Antitrust Policy. Wayne Law Review, 36, Summer 1990, pp. 1413-71.

Kovacic, William E. Creating Competition Policy: Betty Bock and the Development of Antitrust Institutions. Antitrust Law Journal, 66, Fall 1997, pp. 231-45.

Kovacic, William E. The Influence of Economics on Antitrust Law. Economic Inquiry, 30, April 1992, pp. 294-306.

Kovacic, William E. The Federal Trade Commission and Congressional Oversight of Antitrust Enforcement. University of Tulsa Law Journal, 17, 1982, pp. 587-671.

Kovacic, William E. Failed Expectations: The Troubled Past and Uncertain Future of the Sherman Act as a Tool for Deconcentration. Iowa Law Review, 74, 1989, pp. 1105-50.

Letwin, William. Law and Economic Policy in America. New York, Random House, 1965.

Leuchtenburg, William E. Franklin D. Roosevelt and the New Deal, 1932-1940. New York, Harper and Row, 1963.

Link, Arthur S. Woodrow Wilson and the Progressive Era 1910-1917. New York, Harper Torchbook Edition. 1963.

Markham, Jesse W. "An Alternative Approach to the Concept of Workable Competition," American Economic Review, 40, 1950, pp. 349-361.

Markham, Jesse. "The Nature and Significance of Price Leadership," American Economic Review, 41, December 1951, 891-905.

Mason, Edward S. "Price and Production Policies of the Large-Scale Enterprise," American Economic Review, 29, March 1939, 61-74.

May, James. Antitrust in the Formative Era: Political and Economic Theory in Constitutional and Antitrust Analysis, 1880-1918. Ohio State Law Review , 50, 1989, 257-395.

Perelman, Michael. Fixed Capital, Railroad Economics, and the Critique of the Market. Journal of Economic Perspectives, Summer 1994, 189-96.

Robinson, Joan. The Economics of Imperfect Competition. London, Macmillan, 1933.

Salinger, Michael, "The Concentration-Margins Relationship Reconsidered," Brookings Papers on Economic Activity: Microeconomics, 1990, 287-335. 
Scherer, Frederic M. Efficiency, Fairness, and the Early Contributions of Economists to the Antitrust Debate. Washburn Law Review ,29, 1989, _.

Schumpeter, Joseph A., Capitalism, Socialism and Democracy, Hew York, Harper, 1942.

Schumpeter, Joseph A. History of Economy Analysis. New York, Oxford University Press, 1954.

Shapiro, Carl. "The Theory of Business Strategy," Rand Journal of Economics, Spring 1989, pp. 125-37.

Shapiro, Carl. "Theories of Oligopoly Behavior," Handbook of Industrial Organization, R. Schmalensee and R. Willig, eds., Elsevier Science Publishers, 1989.

Simons, Henry C. Economic Policy for a Free Society. Chicago, University of Chicago Press. 1948.

Stigler, George J. "The Kinky Oligopoly Demand Curve and Rigid Prices," Journal of Political Economy, 55, October 1947, pp.

Stigler, George J. Monopoly and Oligopoly by Merger. American Economic Review, 40, May 1950, pp. 23-34.

George Stigler J. "A Theory of Oligopoly," Journal of Political Economy, 72, February 1964, pp. 4461.

Stigler, George J. The Economist as Preacher and Other Essays. Chicago, University of Chicago Press. 1982.

Symposium. The Fire of Truth: A Remembrance of Law and Economics at Chicago. Journal of Law and Economics, 26, 1983, pp. 163-

Thorelli, Hans J. The Federal Antitrust Policy. Baltimore, Johns Hopkins University Press, 1954

1. For example, in State Oil Co. v. Khan, 118 S. Ct. 275, 284 (1997), the Supreme Court emphasized the trend in its previous antitrust decisions of recognizing and adapting to changed circumstances and lessons of accumulated experience. The degree of professional acceptance and empirical verification that economic theories must achieve before they are relied upon in the courtroom remains an issue of debate within the courts. See Gavil (1997).

2. Stigler (1982:41); Thorelli (1954: 117-32, 311-29, 574-75).

3. Ely (1900: 243); Letwin (1965: 71-77); May (1989: 258-59, 287).

4. See Scherer (1989) (recounting views of economists who favored antitrust intervention). 
5. Alfred Marshall (1890) astutely analyzed "complementary monopolists," a topic first addressed by Cournot (1838). Marshall explicitly recognized the advantages of cooperation among firms selling complementary products (which includes companies standing in a vertical rather than horizontal relationship). Unfortunately, courts have been slow to understand the concept, much less to accept it.

6. 166 U.S. 290 (1897).

7. 85 Fed. 271 (6 ${ }^{\text {th }}$ Cir. 1898), aff'd, 175 U.S. 211 (1899).

8. 220 U.S. 373 (1911).

9. 156 U.S. 1 (1895).

10. Northern Securities Co.v. United States, 193 U.S. 197 (1904).

11. 221 U.S. 1 (1911).

12. 224 U.S. 383 (1912).

13. The "essential facilities doctrine" growing out of Terminal Railroad has always been controversial. Some have suggested that the case applies to collective exercise of market power, not merely conduct by a single dominant firm.

14. Compare Hofstadter (1966; 193) (calling the period between World War I and the late 1940s the 'era of neglect' for the antitrust laws).

15. See Hawley (1974).

16. See Hawley (1966).

17. 246 U.S. 231 (1918).

18. 250 U.S. 300 (1919).

${ }^{19} 268$ U.S. 563 (1925). The Court initially took a more doubtful view of information exchanges involving price and output data in American Column \& Lumber v. United States, 257 U.S. 377 (1921).

20. 273 U.S. $392(1927)$.

21. 288 U.S. 344 (1933).

22. 251 U.S. 417 (1920).

23. Fifty years later, economists would develop the "dynamic limit pricing" theory explaining how a dominant firm's market share might gradually erode as it optimally exploited its market power, thus encouraging entry and expansion by rivals. See Gaskins (1971).

24. 283 U.S. 163 (1931).

25. Brandeis's comment is quoted in Link (1963: 74).

Kovacic and Shapiro, Antitrust Policy: A Century of Economic and Legal Thinking, Page 23 
26. 274 U.S. 619 (1927).

27. See Kovacic (1982: 611-17).

28. See Leuchtenberg (1963: 148-49, 154-56, 163).

29. See Kovacic (1989: 1134).

30. See Simons (1948: 87-88).

31. Some prominent free-market economists today are again arguing that antitrust enforcement, as exemplified by the Justice Department's case against Microsoft, is superior to more intrusive regulation of high-technology markets. And Orrin Hatch, Chairman of the Senate Judiciary Committee, has explicitly supported antitrust action against Microsoft in preference to regulation in the form of the "Internet Commerce Commission."

32. 310 U.S. 150 (1940).

33. 346 U.S. 537 (1954).

34. See Northern Pacific Ry. Co.v. United States, 356 U.S. 1 (1958); International Salt Co.v. United States, 332 U.S. 392 (1947).

35. See United States v. Arnold, Schwinn \& Co., 388 U.S. 365 (1967).

36. See Klor's, Inc. v. Broadway-Hale Stores, Inc., 359 U.S. 207 (1959).

37. See Timken Roller Bearing Co. v. United States, 341 U.S. 593 (1951).

38. See United States v. Topco Associates, Inc., 405 U.S. 596 (1972).

39. 148 F.2d 416 (2d Cir. 1945).

40. 110 F. Supp. 295 (D. Mass. 1953), aff'd per curiam, 330 U.S. 806 (1954).

41. 386 U.S. 685 (1967).

42. One exception is Lorain Journal Co.v. United States, 342 U.S. 143 (1951), which condemned a newspaper's efforts to destroy a small radio station by refusing to sell advertising to businesses which advertised on the radio station.

43. 370 U.S. 294 (1962).

44. 374 U.S. 321 (1963).

45. 384 U.S. 270 (1966).

46. 384 U.S. $546(1966)$.

47. See Federal Trade Commission v. Procter \& Gamble Co., 386 U.S. 568 (1967).

48. 384 U.S. at 301 .

Kovacic and Shapiro, Antitrust Policy: A Century of Economic and Legal Thinking, Page 24 
49. By the 1960s, we also see the antecedents of the game-theoretic approach to oligopoly that would soon dominate industrial organization. Much of that huge literature can be traced back to Stigler's (1964) classic article. For an extensive review of the literature on oligopoly theory through the 1980s, see Shapiro (1989).

50. From a modern perspective, cross-sectional studies of this kind are inevitably limited by the quality of the data on market structure, which relates to the thorny problem of accurately delineating the market's boundaries, much less measuring market shares and entry conditions. For a review of this literature, see Michael Salinger (1990).

51. Director's role in the move from the trustbusting tradition of the old Chicago School to the new Chicago School's efficiency orientation is discussed in Stigler (1982: 166-70); Symposium (1983).

52. The role of scholars such as Bock, Bork, Easterbrook, Gellhorn, and Posner as 'translators' is studied in Kovacic (1989; 1992; 1998).

53. 433 U.S. 36 (1977).

54. See Monsanto Co.v . Spray-Rite Service Corp., 465 U.S. 752 (1984); Business Electronics Corp. v. Sharp Electronics Corp., 485 U.S. 717 (1988).

55. 457 U.S. 332 (1982).

56. 493 U.S. 411 (1990).

57. 441 U.S. 1 (1979).

58. 468 U.S. 84 (1984).

59. See Federal Trade Commission v. Indiana Federation of Dentists, 476 U.S. 447 (1986).

60. 552 F. Supp. 131 (D.D.C. 1982), aff'd sub nom. Maryland v. United States, 460 U.S. 1001 (1983).

61. See Matsushita Electric Industrial Co. v. Zenith Radio Corp., 475 U.S. 574 (1986).

62. See Berkey Photo, Inc.v. Eastman Kodak Co., 603 F.2d 263 (2d Cir. 1979).

${ }^{63}$ Judicial decisions involving monopolization in this period generally favored defendants. A major exception to this trend emerged in United States v. Otter Tail Power Co., 410 U.S. 366 (1973) and Aspen Skiing Co. v. Aspen Highlands Skiing Corp., 472 U.S. 585 (1985), where the Supreme Court ruled that dominant firms may have a broad duty to deal with rivals, particularly where they own assets with natural monopoly characteristics.

64. 415 U.S. 486 (1974).

65. See United States v. Waste Management, Inc., 743 F.2d 976 (2d Cir. 1984); United States v. Syufy Enterprises, 903 F.2d 659 ( $9^{\text {th }}$ Cir. 1990).

66. See Federal Trade Commission v. University Health, Inc., 938 F.2d 1206 (11 ${ }^{\text {th }}$ Cir. 1991) (rejecting efficiency arguments of merging parties but treating efficiency claims as relevant to merger analysis).

67. 908 F.2d 981 (D.C. Cir. 1990).

Kovacic and Shapiro, Antitrust Policy: A Century of Economic and Legal Thinking, Page 25 
68. The Department of Justice and Federal Trade Commission Horizontal Merger Guidelines are reprinted at 4 Trade Regulation Reporter (Commerce Clearing House) Para. 13,104.

69. 475 U.S. 574 (1986).

${ }^{70}$ For an illustration of the many applications of game theory to antitrust and competitive strategy issues, see Shapiro (1989). For a criticism of this line of research due to its lack of general predictions, see the companion piece, Fisher (1989).

71. See Baker (1999).

72. 119 S. Ct. 1604 (1999).

73. United States v. Visa U.S.A. Inc. and MasterCard Int'1, Inc., Civil Action No. 98-civ-7076 (MP) (S.D.N.Y. filed Oct. 7, 1998).

74. See Federal Trade Commission and U.S. Department of Justice, Draft Antitrust Guidelines for Collaborations Among Competitors (Oct. 1, 1999).

75. U.S. Department of Justice, Corporate Leniency Policy (Aug. 10, 1993); U.S. Department of Justice, Leniency Policy for Individuals (Aug. 10, 1994).

76. U.S. Department of Justice, F. Hoffmann-La Roche and BASF Agree to Pay Record Criminal Fines for Participating in International Vitamin Cartel (May 20, 1999) (press release on fines), available at <http://www.usdoj.gov/atr/public/press_releases/1999/2450.htm>.

77. See United States v. Airline Tariff Publishing Co., 1994-2 Trade Cas. (CCH) Para. 70,687 (D.D.C. 1994) (final consent decree).

78. 504 U.S. 451 (1992).

79. Ironically, Kodak did not in fact act opportunistically by changing its policies after building up an installed base of users. The claim of "installed-base opportunism," which the Supreme Court indicated could constitute an antitrust violation. was not pursued in the subsequent trial. However, Kodak stands for the principle that strategic behavior, including conduct based on imperfect consumer information, must be examined in detail by the trial court.

80. 509 U.S. 209 (1993).

81. United States v. AMR Corp., Civ. Action No. 99-1180-JTM (D. Kan. filed May 13, 1999) (Justice Department complaint), available at <http://www.usdoj.gov/atr/cases/f2400/2438.htm>.

82. The Supreme Court's most recent word on substantive merger standards appeared in United States $v$. Citizens and Southern National Bank, 422 U.S. 86 (1975).

83. Federal Trade Commission v. Staples, Inc., 970 F. Supp. 1066 (D.D.C. 1997).

84. U.S. Department of Justice and Federal Trade Commission, Antitrust Guidelines for the Licensing of Intellectual Property, reprinted in 5 Trade Reg. Rep. (CCH) Para. 13,132 (Apr. 6, 1994).

85. In re Intel, 5 Trade Reg. Rep. (CCH) Para. 24,440 (F.T.C. filed June 8, 1998).

Kovacic and Shapiro, Antitrust Policy: A Century of Economic and Legal Thinking, Page 26 
86. United States v. Microsoft Corp., No. 98-1232, 6 Trade Reg. Rep. (CCH) Para. 45,098 (D.D.C. filed May 1998) (Justice Department complaint)..

87. See Sugar Institute, Inc. v. United States, 297 U.S. 553 (1936) ( We have said that the Sherman Anti-Trust Act, as a charter of freedom, has a generality and adaptability comparable to that found to be desirable in constitutional provisions.'). 